\title{
EVALUATION OF DEVELOPMENT EFFICIENCY OF BRIGJEND SUDIARTO BUSINESS TOWARDS MOSQUITOON ON SIMPANG MODELING
}

\author{
Muhammad Teqi Wijaya ${ }^{1}$, Kartono Wibowo ${ }^{2}$ \\ ${ }^{I}$ The Department Master of Civil Engineering, Faculty of Engineering, Sultan Agung Islamic University, \\ Jl. Raya Kaligawe Km. 4 Semarang, 50112, Indonesia \\ Corresponding Author Email : kartonowibowo@yahoo.co.id
}

\begin{abstract}
This research aims to examine the efficiency of Brigjend Soediarto fly over development towards the traffic jam in Pedurungan intersection. The approach conducted in this research is quantitative paradigm, with the quantitative method in the process of analysis. According to the analysis, the recent condition indicates high traffic flows density in each intersection. The level of service (LOS) in Brigjend Soediarto road is 1,421 in the F level. It is predicted that after the development of fly over, the level of service increasse into $C$ with LOS $=0.579$. Meanwhile, the LOS in Soekarno-Hatta road is 0.854 with the D level, and increases into B level with LOS = 0.226. While LOS Fatmawati road is 0.856 with the D level and increases into B with $L O S=0.284$. Before the development, the vehicle speed in Pedurungan intersection was 5.914 $\mathrm{km} / \mathrm{hour}$. After the development is is predicted that the vehice speed will be $49.885 \mathrm{~km} / \mathrm{hour}$. So that the average speed is $43.97 \mathrm{~km} / \mathrm{hour}$. Based on those analysis, the efficiency of the development of Brigjend Soediarto fly over is $76.28 \%$. It can be concluded by the development of Brigjend Soediarto fly over, it is efficiently increasing the flow of traffic in Pedurungan intersection.
\end{abstract}

Keywords : Brigjend Soediarto Fly Over, Pedurungan Intersection, Traffic Delay

\section{INTRODUCTION}

The road is a land-linking infrastructure used for human traffic and goods from one place to another. In addition to the aspect of spatial planning activities, the road network has the benefit of directing the growth of an area in which it passes. As already stipulated in Regional Regulation no. 14 of 2011 on Spatial Planning of Semarang City, Semarang City set a plan of transportation network structure intended to direct the distribution of transportation services and the development of Semarang City area.

The pattern of the road network plan in Semarang City is broadly developed with Radial (centering) and Concentric (circular) patterns. Radial pattern is a pattern of road network connecting Semarang city and hinterland cities (towards Kendal / Jakarta, Demak / Surabaya, Mranggen / Purwodadi, Ungaran / Surakarta / Yogyakarta and towards Boja). The concentric road network pattern is the Inner Ring Road network 
plan, the Middle Ring Road and the Outer Ring Road. The plan to be developed is the road network plan J1. Brigadier Soediarto, especially at Pedurungan intersection that will connect between Jalan Brigjend Soediarto with Fatmawati Street and SoekarnoHatta Road.

In the present condition, Jalan Brigjend Sudiarto segment at this pedurungan intersection especially in the morning and afternoon suffered severe congestion. This is due to the two adjacent intersections of the intersection between Soekarno - Hatta Artery Street with Jalan Brigjend Sudiarto and the intersection between Fatmawati Street and Jalan Brigjend Sudiarto.

To improve the smoothness and to overcome such situations, a solution is needed to smooth the junction. One approach that is used is to build interchanges so as to increase the capacity of the intersection.

\section{RESEARCH PURPOSES}

1. Evaluate the impact of Brigjend Sudiarto interchanges in overcoming the congestion in Simpang Pedurungan.

2. Knowing the percentage of congestion levels that can be derived with the construction of the interchanges of Brigjend Sudiarto.

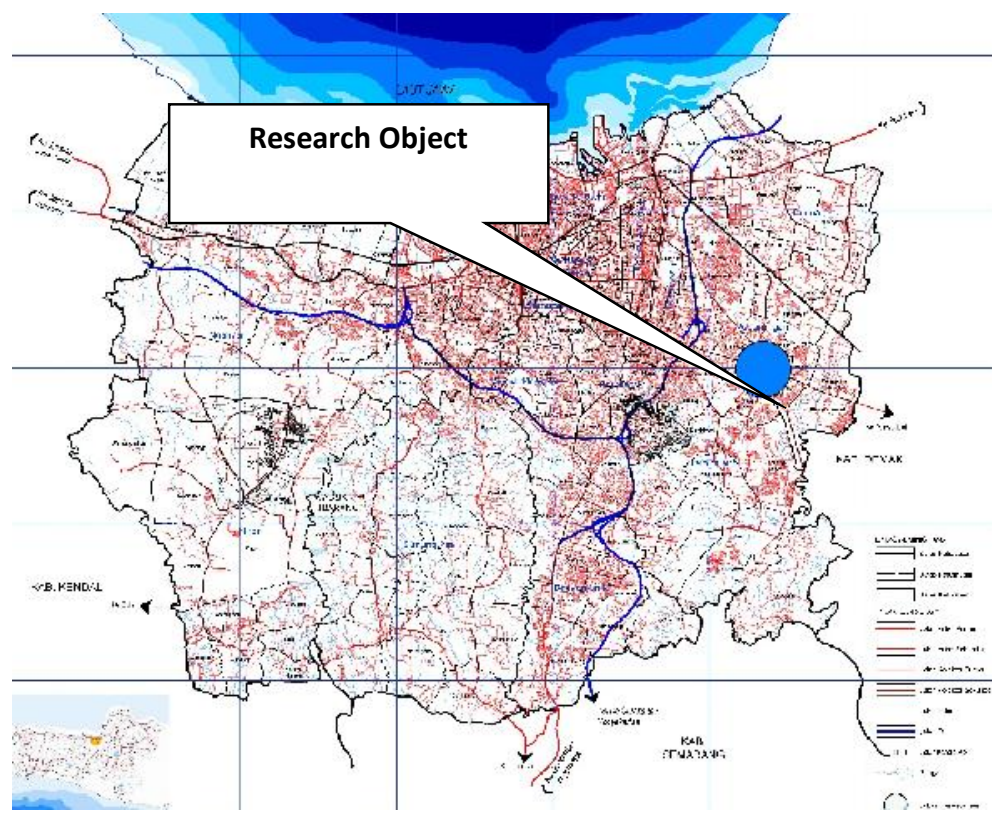

Figure Error! No text of specified style in document. Location of Research Area 
Vol 23 No 1 Tahun 2018

\section{METHODOLOGY}

\section{Vehicle Flow Analysis}

Vehicle current analysis includes vehicle speed analysis and vehicle volume analysis. This analysis aims to determine the change in the amount of traffic flow before the Fly Over with the presence of Fly Over.

By knowing the difference in the flow of vehicles passing Jalan Brigjend Sudiarto, Jalan Fatmawati and Jalan Arteri Soekarno Hatta, we can know the capacity of each road segment so that it can be used to calculate the capacity of the road before the interchange with after the interchanges at the peak hour.

\section{Simpang analysis}

Traffic flow smoothly if it can cross the intersection without experiencing obstacles or interference, so that the flow does not experience traffic problems. This can be caused by many factors that can affect the efficiency and safety of travel on the highway.

The analysis is calculated against the current condition data to see the capability and capacity of the road. By knowing the condition of the intersection at the intersection of Sudiarto brigjend it can be seen how effective the intersection plan can solve the congestion problem at this intersection.

\section{Efficiency Analysis}

Efficiency is one of the criteria used in assessing a feasibility. Efficiency is used to select a number of alternatives that are used as a reference to determine the choice of alternatives by looking at the benefits or benefits of each alternative.

By comparing the road capacity of each road segment with prior to built Simpang Susun and after built Simpang Susun can be known how efficient the construction of Simpang Susun Jalan Brigjend Sudiarto In solving congestion problem at intersection of Koata Pedurungan Semarang.

\section{DISCUSSION AND ANALYSIS}

Existing condition analysis that will be done is to calculate the capacity and condition of $\mathrm{V} / \mathrm{C}$ ratio of existing condition for Road segment at Simpang stack 
Brigjend Sudiarto Semarang City, which is Jalan Brigjend Sudiarto Street, Sukarno Hatta Artery Road, and Fatmawati Street.

The road capacity is defined as the maximum current that can be maintained union of clock passing through a point on the road under existing conditions. For a two-lane two-way street, the capacity is defined for two-way flow, but for multiple lane roads, currents are separated travel direction and defined capacity of the crotch.

Capacity expressed in units of passenger cars per hour (smp / hour). The basic equation for determining capacity is as follows:

C = Co X FCw X FCsp X FCsf X FCes

Note:

$\mathrm{C} \quad=$ Capacity (smp/jarn)

Co = Basic Capacity (snip/jam)

$\mathrm{FCw}=$ Factor of road width adjustment

FCsp = Segregation adjustment factor (for unbounded paths)

FCsf = Adjustment factor side barriers and road shoulders

FCcs = Adjustment factor based on city size

Based on the results of the primary survey conducted obtained traffic conditions in each segment. Existing condition is in the form of the number and fluctuations of vehicles along with the percentage of vehicles passing on each segment in the affected area. In addition, the analysis of the prediction of conditions at the time of interchanges have been established, the results of the analysis are as follows:

Table 4.1 Survey Results of Road Traffic Survey Brigjend Soediarto

\begin{tabular}{clcr}
\hline No & \multicolumn{1}{c}{ Factor Analysis } & Description & Value \\
\hline 1 & Basic Capacity (Co) smp / hour & 4 Divided Lines & 6,600 \\
2 & Road Width Adjustment Factor (FCw) & $4 \mathrm{D}, \mathrm{Wc}=4$ & 1.08 \\
3 & The Direction Direction Adjustment Factor (FCsp) & $50-50$ & 1.00 \\
4 & Side Adjustment Adjustment Factor (FCsf) & $4 / 2 \mathrm{D}, \mathrm{M}$ & 0.93 \\
5 & City Size Adjustment Factor (FCcs) & $0.5-1.0 \mathrm{Million}$ Souls & 0.94 \\
\hline & & Capacity ( C ) smp/hour & $6,231.3$ \\
& & V peak smp/hour & $8,852.2$ \\
\cline { 3 - 4 } & & V/C Ratio & $\mathbf{1 . 4 2 1}$ \\
\hline
\end{tabular}


Based on the value of the $\mathrm{V} / \mathrm{C}$ ratio it can be said that this road segment has a huge obstacle and delay on traffic service at peak traffic hour.

With the interchanges, the value of V / C ratio of Brigjend Sudiarto road segment will be small due to the distribution of traffic flow through each segment so that the road capacity will increase from the calculation result obtained V / C ratio of Brigjend Sudiarto road segment is as follows

Table 4.2 Survey Results of Road Traffic Survey Brigjend Soediarto with interchanges

\begin{tabular}{clcc}
\hline No & \multicolumn{1}{c}{ Factor Analysis } & Description & Value \\
\hline 1 & Basic Capacity (Co) smp / hour & 4 Divided Lines & 9,900 \\
2 & Road Width Adjustment Factor (FCw) & $4 \mathrm{D}, \mathrm{Wc}=4$ & 1.08 \\
3 & The Direction Direction Adjustment Factor (FCsp) & $50-50$ & 1.00 \\
4 & Side Adjustment Adjustment Factor (FCsf) & $4 / 2 \mathrm{D}, \mathrm{VL}$ & 0.99 \\
5 & City Size Adjustment Factor (FCcs) & $0.5-1.0 \mathrm{Million}$ Souls & 0.94 \\
\hline & & Capacity ( C ) smp/hour & $9,949.98$ \\
& & V peak smp/hour & $5,757.61$ \\
& & V/C Ratio & $\mathbf{0 . 5 7 9}$ \\
\cline { 3 - 4 }
\end{tabular}

Based on the value of $\mathrm{V} / \mathrm{C}$ ratio it can be said that this roadway is relatively stable to traffic service at peak hour traffic

Table 4.3 Survey Result of Traffic Survey of Jalan Arteri Soekarno Hatta

\begin{tabular}{clcc}
\hline No & \multicolumn{1}{c}{ Factor Analysis } & Description & Value \\
\hline 1 & Basic Capacity (Co) smp / hour & 4 Divided Lines & 6,600 \\
2 & Road Width Adjustment Factor (FCw) & $4 \mathrm{D}, \mathrm{Wc}=4$ & 1.08 \\
3 & The Direction Direction Adjustment Factor (FCsp) & $50-50$ & 1 \\
4 & Side Adjustment Adjustment Factor (FCsf) & $4 / 2 \mathrm{D}, \mathrm{H}$ & 0.88 \\
5 & City Size Adjustment Factor (FCcs) & $0.5-1.0$ Million Souls & 0.94 \\
\hline & & Capacity ( C ) smp/hour & $5,896.282$ \\
& & V peak smp/hour & 5036.8 \\
\cline { 3 - 4 } & & V/C Ratio & $\mathbf{0 . 8 5 4}$ \\
\hline
\end{tabular}

Based on the value of $\mathrm{V} / \mathrm{C}$ ratio it can be said that this road has been unstable speed sometimes stalled and demand is approaching peak to traffic service at peak hour traffic. 
With the interchanges, the value of V / C ratio of Soekarno Hatta road will be small due to the distribution of traffic flow through each segment and the increase of road capacity. The calculation results obtained V / C ratio of Soekarno Hatta road is as follows.

Table 4.4 Survey Results of Road Traffic Survey Soekarno Hatta road with interchanges

\begin{tabular}{clcc}
\hline No & \multicolumn{1}{c}{ Factor Analysis } & Description & Value \\
\hline 1 & Basic Capacity (Co) smp / hour & 4 Divided Lines & 9,900 \\
2 & Road Width Adjustment Factor (FCw) & $4 \mathrm{D}, \mathrm{Wc}=4$ & 1.08 \\
3 & The Direction Direction Adjustment Factor (FCsp) & $50-50$ & 1 \\
4 & Side Adjustment Adjustment Factor (FCsf) & $4 / 2 \mathrm{D}, \mathrm{H}$ & 0.87 \\
5 & City Size Adjustment Factor (FCcs) & $0.5-1.0$ Million Souls & 0.94 \\
\hline & & Capacity ( C ) smp/hour & $8,743.918$ \\
& & V peak smp/hour & $1,979.582$ \\
\cline { 2 - 3 } & & V/C Ratio & $\mathbf{0 . 2 2 6}$ \\
\hline
\end{tabular}

Based on the value of $\mathrm{V} / \mathrm{C}$ ratio, it can be said that the road is relatively much to traffic service at peak traffic hour.

\section{Table 4.5 Survey Result of Traffic Survey of Fatmawati Road}

\begin{tabular}{clcc}
\hline No & \multicolumn{1}{c}{ Factor Analysis } & Description & Value \\
\hline 1 & Basic Capacity (Co) smp / hour & 4 Divided Lines & 6,000 \\
2 & Road Width Adjustment Factor (FCw) & 4UD,Wc $=3.5$ & 1.00 \\
3 & The Direction Direction Adjustment Factor (FCsp) & $50-50$ & 1.00 \\
4 & Side Adjustment Adjustment Factor (FCsf) & $4 / 2 \mathrm{UD}, \mathrm{H}$ & 0.87 \\
5 & City Size Adjustment Factor (FCcs) & $0.5-1.0$ Million Souls & 0.94 \\
\hline & & Capacity ( C ) smp/hour & $4,906.8$ \\
& & V peak smp/hour & $4,200.2$ \\
& & V/C Ratio & $\mathbf{0 . 8 5 6}$ \\
\cline { 2 - 3 }
\end{tabular}

Based on the value of $\mathrm{V} / \mathrm{C}$ ratio it can be said that this road has been unstable speed sometimes stalled and demand is approaching peak to traffic service at peak hour traffic

With the interchanges, the value of $\mathrm{V} / \mathrm{C}$ ratio of Fatmawati road will be small due to the distribution of traffic flow through each segment as well as the increase of 
road capacity. The calculation results obtained V / C ratio of Fatmawati road is as follows:

Table 4.6 Survey Result of Traffic Survey of Fatmawati Road with interchanges

\begin{tabular}{clcc}
\hline No & \multicolumn{1}{c}{ Factor Analysis } & Description & Value \\
\hline 1 & Basic Capacity (Co) smp / hour & 4 Divided Lines & 9,000 \\
2 & Road Width Adjustment Factor (FCw) & 4UD,Wc $=3.5$ & 1.00 \\
3 & The Direction Direction Adjustment Factor (FCsp) & $50-50$ & 1.00 \\
4 & Side Adjustment Adjustment Factor (FCsf) & $4 / 2 \mathrm{UD}, \mathrm{H}$ & 0.87 \\
5 & City Size Adjustment Factor (FCcs) & $0.5-1.0$ Million Souls & 0.94 \\
\hline & & Capacity ( C ) smp/hour & $7,360.2$ \\
& & V peak smp/hour & $2,088.58$ \\
& & V/C Ratio & $\mathbf{0 . 2 8 4}$ \\
\hline
\end{tabular}

From the value of $\mathrm{V} / \mathrm{C}$ ratio, it can be said that this road segment is still much relative to traffic service at peak hour of traffic.

\section{Results of Analysis of Junction Simpang JI. Brigadier Soediarto with Soekarno Hatta Artery Street}

The use of Traffic Signal Signal at the road meeting between Jl. Brigadier General Sudiarto with Jl. Soekarno Hatta Artery aims to:

a. To avoid traffic congestion due to conflict of traffic flow around the road meeting.

b. To reduce the number of traffic accidents occurring in the road encountered by a collision between vehicles from opposite directions.

According to observations and analysis of the amount of traffic flow is quite high, especially on the arms of the West and East arm.

The amount of current $(\mathrm{Q})$ in and out of the arm is very large and there will be an increase in road capacity:
i. Out of the north arm $\quad: 530 \mathrm{smp} / \mathrm{jam}$
ii. Out of the east arm : $1009 \mathrm{smp} / \mathrm{jam}$
iii. Out of the west arm : $778 \mathrm{smp} / \mathrm{jam}$ 


\section{Results of the Junction Analysis of Jl. Brigadier Soediarto with Fatmawati Street.}

The use of Traffic Signal Signal at the road meeting between Jl. Brigadier General Sudiarto with Jl. Fatmawati aims to:

a. To avoid traffic congestion due to conflict of traffic flow around the road meeting.

b. To reduce the number of traffic accidents occurring in the road encountered by a collision between vehicles from opposite directions.

According to observations and analysis of the amount of traffic flow is quite high, especially on the arms of the West and East arm.

The amount of current $(\mathrm{Q})$ in and out of the arm is very large and there will be an increase in road capacity:
i. Out of the north arm
: $530 \mathrm{smp} / \mathrm{hour}$
ii. Out of the east arm
: $1120 \mathrm{smp} / \mathrm{hour}$
iii. Out of the west arm
: $669 \mathrm{smp} / \mathrm{hour}$

\section{CONCLUSION}

Based on the results of analysis and studies that have been done as written in the previous chapter, it can be concluded as follows: Based on the analysis that has been done can be seen that the value of LOS (level of service) segment Jl. Brigadier Sudiarto prior to the interchanges obtained value of LOS $=1.421$ then for the Level of Service Road Brigjen Sudiarto that has the value of $\mathrm{F}$, which is said that the road has a characteristic of the current is inhibited, low speed, volume above capacity, frequent congestion in a long time. while the prediction after the interchanges of road service level increased to $\mathrm{C}$ with the value of $\operatorname{LOS}=0.579$ so it can be said that the road is relatively stable at the peak hour service.

While the Artery Road Soekarno Hatta obtained LOS value of 0.854 for Soekarno Hatta Armed Street Service Level that has a value D, which can be said that the road has karasteristik flow start unstable, low speed and different, the volume of vehicles approaching the capacity of the road there is. After the interchanges the level of road service increased to B with the value of $\operatorname{LOS}=0.226$ so it can be said that the road is relatively still many at the peak hour service. 
The Fatmawati road segment obtained LOS value is 0.856 for Fatmawati Road Service Level that has a value D, which can be said that the road has karasteristik flow start unstable, low speed and different, the volume of vehicles approaching the existing road capacity. After the interchanges the level of road service increased to B with the value of $\operatorname{LOS}=0.284$ so it can be said that the road is relatively still a lot at the peak hour service.

\section{REFERENCE}

-------. 2008, Masterplan Transportasi Kota Semarang. Semarang: Badan Perencanaan Pembangunan Daerah Kota.

-------. 2009, Study Kelayakan Midle Ring Road Kota Semarang. Semarang: Badan Perencanaan Pembangunan Daerah Kota.

Betty One William. 2010. Analisis Pembebanan Jaringan Jalan dengan Memasukkan Angkutan Umum menggunakan Aplikasi Software Emme/3 (Studi Kasus Kota Surakarta). Surakarta: Tugas Akhir, Sarjana Teknik Sipil, Universitas Sebelas Maret.

Branch, C. Melville. 1996. Perencanaan Kota Komprehensif: Pengantar dan Penjelasan. Penerjemah: Bambang Hari Wibisono, Penyunting: Achmad Djunaedi. Yogyakarta: Gadjah Mada University Press.

Direktorat Jenderal Bina Marga. 1990. Tata Cara Penyusunan Program Pemeliharaan Jalan Kota.Jakarta.Direktorat Pembinaan Jalan Kota.

Erizal, 2003. Evaluasi Ruas Jalan Arteri Primer (sttudi kasus ruas jalan Sudirman di kota Bekasi),Bekasi : Tesis Magister, Program Magister Teknik Pembangunan Wilayah Dan Kota, Universitas Diponegoro.

Iskandar Abubakar, Ir., MSc., Judiza RZ, Ir., MSc., Besty Ernani, Ir., MRUP., Trisupono, SH., Edy Sutiono, A.TD., Ahmad Yani, A.TD. (1996) "Manajemen Transportasi Perkotaan", Jakarta :Sekretariat Masyarakat Transportasi Indonesia.

Jayadinata,Johara.T.1999, Tata Guna Tanah Dalam Perencanaan Pedesaan Perkotaan dan Wilayah. Bandung : Institut Teknologi Bandung.

Hobbs F.D,1979.Traffic Planning and Engineering,second edition,Edisi Indonesia, 1995, terjemahan Suprapto T.M. dan Waldijono, Perencanaan dan Teknik Lalu Lintas , Edisi Kedua, Yogyakarta: Gadjah Mada University Press. 
Vol 23 No 1 Tahun 2018

Macket, 1994.Evaluating Traffic Impact Studies,A Recommended Practice For Michigan Communities.United States

Miro, Fidel. 1997. Sistem Transportasi Kota. Bandung: Tarsito

Nasution, HMN. 1996. Manjemen Transportasi. Jakarta: Ghalia Indonesia.

Oglesby,C.H,Hicks,R.G,1982.Highway Engineering,Fourth Edition, Edisi Indonesia, 1993, Terjemahan Purwo Setiono, Teknik Jalan Raya edisi ke empat, jilid I,Jakarta :Penerbit Erlangga

Pradana, Tata. 2004. Analisis Dampak Lalu Lintas Pembangunan Masjid Agung Jawa Tengah di Kota Semarang. Semarang: Tesis Magister, Program Magister Teknik Sipil, Universitas Diponegoro.

Salim, Abbas. 1993. Manajemen Transportasi. Jakarta: PT. Raja Grafindo Persada.

Salter, R.J. 1989. Highway Traffic Analysis and Design. Second Edition, Mac Millan Education, Ltd. London.

Subechi, Arief. 2007. Analisis Dampak Lalu - Lintas (Andalalin) Pada Pusat Perbelanjaan YANG Telah Beroperasi Ditinjau Dari Tarikan Perjalanan (Studi Kasus Pada Pacific Mall Tegal). Semarang: Tesis Magister, Program Magister Teknik Sipil Jurusan Manajemen Rekayasa Infrastruktur, Universitas Diponegoro.

Sunarto. 2005. Analisa Dampak Lalu Lintas Dibangunnya Terminal Mangkang Pada Ruas Jalan Rute Bus Luar Kota di Kota Semarang (Studi Kasus : Pengaruh Pembebanan Lalu Lintas AKAP dan AKDP). Semarang: Tesis Magister, Program Magister Teknik Sipil, Universitas Diponegoro.

Sweroad, PT Bina Karya (PERSERO). 1997. Manual Kapasitas Jalan Indonesia (MKJI). Jakarta : Direktorat Jenderal Bina Marga Direktorat Bina Jalan Kota (BINKOT).

Syafii. 2011. Bahan Ajar Magister Rekayasa Trasportasi. Semarang: Universitas Islam Sultan Agung.

Tata Pradana. 2004. Analisis Dampak Lalu Lintas Pembangunan Masjid Agung Jawa Tengah di Kota Semarang. Semarang: Tesis Magister, Program Magister Teknik Sipil, Universitas Diponegoro.

Tamin, OZ. 2000. Perencanaan dan Pemodelan Transportasi. Jakarta: Erlangga.

Undang - Undang No. 22 Tahun 2009. Tentang Lalu Lintas dan Angkutan Jalan. Jakarta: Kementrian Pekerjaan Umum. 
Undang - Undang No. 38 Tahun 2004. Tentang Jalan. Jakarta: Kementrian Pekerjaan Umum.

William, Betty. 2010. Analisis Pembebanan Jaringan Jalan dengan Memasukkan Angkutan Umum menggunakan Aplikasi Software Emme/3 (Studi Kasus Kota Surakarta). Surakarta: Tugas Akhir Progrtam Sarjana Teknik Sipil Universitas Sebelas Maret.

Yeates, M and B. Gardner. 1980. The North American Cities. Third Edition. Ontario: Queen's University Ontario.

Dr. Eng. Syafii , Bahan Ajar Magister Rekayasa Trasportasi, Universitas Islam Sultan Agung Semarang

CV. Piramida Kreasi Mandiri, DED Simpang Susun Brigjend Sudiarto Tahun Anggaran 2017, Dinas Pekerjaan Umum Kota Semarang. 